\title{
Assessment of proteolysis and sensory characteristics of Prato cheese with adjunct culture
}

\section{Avaliação da proteólise e das características sensoriais de queijo Prato com cultura adjunta}

\author{
Rafael Tamotsu Sato; ; Ariane Tayla Bisca Vieira ${ }^{2}$; Jaqueline Camisa ${ }^{3}$; \\ Priscila Cristina Bizam Vianna ${ }^{4}$; Christiane Maciel Vasconcellos Barros De Rensis ${ }^{4^{*}}$
}

\begin{abstract}
Influence of adjunct cultures on the chemical and sensory characteristics, and proteolysis of Prato cheese was investigated. Cheeses were manufactured using a commercial starter culture and Lactobacillus strains (Lactobacillus plantarum or Lactobacillus helveticus) as adjunct cultures. Control cheeses lacked the adjunct culture. The chemical composition was analyzed at day 5 after manufacture and the proteolysis at days 5, 25, 45 and 65 of ripening. The sensory acceptance was assessed at 60 days. A split-plot design was used and the complete experiment was carried out in triplicate. The results were evaluated by ANOVA and Tukey's test test at $5 \%$ significance level. There were no significant differences in chemical composition among the cheeses. A significant increase in proteolysis occurred during ripening period for the cheeses with adjunct culture when compared to cheeses without adjunct culture. Cheese with Lactobacillus helveticus showed higher scores for flavor, texture and purchase intent compared with the others treatments. Use of adjunct Lactobacillus suggests that the proteolysis of Prato cheese should be accelerated in order to reduce ripening period.
\end{abstract}

Key words: Adjunct culture, cheese, flavor, proteolysis, sensory analysis

\section{Resumo}

A influência de culturas adjuntas sobre as características químicas e sensoriais, e sobre a proteólise do queijo Prato foi avaliada. Os queijos foram fabricados com cultura starter comercial e cepas de Lactobacillus (Lactobacillus plantarum ou Lactobacillus helveticus) como culturas adjuntas. Os queijos controle não foram adicionados de cultura adjunta. A composição química foi analisada no dia 5 após a fabricação e a proteólise nos dias 5, 25, 45 e 65 de maturação. A aceitação sensorial foi avaliada após 60 dias. Um delineamento de parcelas subdivididas foi utilizado e o experimento completo foi realizado em triplicata. Os resultados foram avaliados pela análise de variância e teste de Tukey no nível de 5\% de probabilidade. Os queijos não apresentaram diferenças significativas em relação à composição química. Um aumento significativo na proteólise ocorreu durante o período de maturação para os queijos com cultura adjunta, quando comparado aos queijos sem adição desse tipo de cultura. Os queijos com Lactobacillus helveticus apresentaram médias das notas mais altas para os atributos sabor, textura e intenção de compra em comparação aos demais tratamentos. A utilização de Lactobacillus como cultura adjunta indica que a proteólise do queijo prato pode ser acelerada a fim de reduzir o seu tempo de maturação.

Palavras-chave: Análise sensorial, cultura adjunta, queijo, proteólise, sabor

\footnotetext{
${ }^{1}$ Bolsista Iniciação Científica Funadesp, Curso de Graduação em Farmácia, Universidade Norte do Paraná, UNOPAR, Londrina, PR. E-mail: rafael sat0@hotmail.com

${ }^{2}$ Bolsista PIBIC/CNPq, Curso de Graduação em Engenharia de Alimentos, UNOPAR, Londrina, PR. E-mail: arianebisca@hotmail.com

${ }^{3}$ Discente de Mestrado em Ciência e Tecnologia do Leite, UNOPAR, Londrina, PR. E-mail: jaque_camisa@hotmail.com

${ }^{4}$ Profs. Pesquisadores do Mestrado em Ciência e Tecnologia do Leite, UNOPAR, Londrina, PR. E-mail: priscila.vianna@unopar. br; christiane@unopar.br

* Author for correspondence
} 


\section{Introduction}

Prato cheese is one of the most produced and consumed cheese in Brazil. During the ripening period, it develops soft texture and mild flavor, as a result of biochemical reactions. It is very appreciated by consumers, and may be used as a table cheese or as a culinary ingredient (COSTA JUNIOR; PINHEIRO, 1998).

The ripening process is decisive for the development of suitable texture and sensory properties for many types of cheese (SOUZA; ARDÖ; MCSWEENEY, 2001), and the proteolysis is the main indicator of ripening (FOX; SINGH; MCSWEENEY, 1995). The understanding of the biochemistry of cheese ripening enables to control it during the process to obtain better quality cheeses (FOX, 1998).

Several approaches have been adopted for monitoring the biochemistry process and establishing the optimal ripening period to prevent excessive proteolysis, which contributes to the formation of low-molecular-mass hydrophobic bitter peptides, undesirable in cheese (MISTRY, 2001).

The optimal ripening period for Prato cheese is approximately 40 days. However, Brazilian legislation allows the product to be marketed after 25 days of storage (BRASIL, 1997), which is an insufficient time to develop the desirable sensory characteristics, therefore causing low quality and economic losses in the cheese industry (SILVA; VAN DENDER; BALDINI, 1999). Cheese ripening is a relatively expensive process for the cheese industry due to the slow-ripening process (SIUFE; ZORRILLA; RUBIOLO, 2010).

However, there are alternative technologies to accelerate the ripening of cheeses. A possible approach is the use of adjunct cultures, that contribute to a short lead time of ripening and, consequently, economic losses are reduced (DRAKE; SWANSON, 1995). The use of adjunct cultures can accelerate flavor development of the cheese through the increase of proteolysis, especially due to amino peptidase activity, which reduces the bitter taste and increases the concentration of desirable flavored peptides and volatile flavor precursors (SILVA et al., 2004).

Lactobacilli are the most common microorganisms used as adjunct culture in cheese production. Lactobacillus helveticus and Lactobacillus plantarum, added during cheese production, contribute to the increase of proteolysis, development of desirable flavors and decrease of bitter flavors (BARROS et al., 2006; DRAKE; BOYLSTON; SWANSON, 1996).

The objective of this study was to evaluate the effect of the use of Lactobacillus helveticus and Lactobacillus plantarum as adjunct culture on the sensory characteristics and proteolysis of Prato cheese.

\section{Material and Methods}

\section{Cheese manufacture}

Raw milk was standardized with skim milk to obtain a final fat content of $3.0 \%$ and heat treated at $65^{\circ} \mathrm{C}$ for $30 \mathrm{~min}$ in a double wall tank (TMS 100 Incomar, Chavantes/SP, Brazil). The pasteurized standardized milk was cooled to $35^{\circ} \mathrm{C}$ and divided into three equal parts to be used for Prato cheese manufacture. The following treatments were carried out: 1) the control cheese (QC) using traditional mesophilic culture $(1 \% \mathrm{v} / \mathrm{v})$ MA11 - Lactococcus lactis subsp. lactis, Lactococcus lactis subsp. cremoris; 2) cheese produced with traditional mesophilic culture and Lactobacillus plantarum (CHOOZIT FLAV 14 LYO 5D, 1\% v/v; Q14); 3) cheese produced with traditional mesophilic culture and Lactobacillus helveticus (CHOOZIT FLAV 54 LYO 5D, 1\% v/v; Q54). The cultures were supplied by Danisco ${ }^{\circledR}$ (Copenhagen, DK). The three processing procedures, one for each treatment, were carried out the same day and repeated three times, resulting in a total of nine tests previously randomized. 
For each cheese, $50 \%$ calcium chloride solution (250 ppm) was added to the milk at $35^{\circ} \mathrm{C}$, followed by the addition of mesophilic and adjunct culture (when used), annatto dye (80 ppm) and rennet (Bela Vista $^{\circledR}$, São Paulo/SP, Brazil) sufficient to coagulate the milk within $35 \mathrm{~min}$.

After coagulation, the curd was cut into $0.5 \mathrm{~cm}$ cubes and submitted to slow continuous mixing for $15 \mathrm{~min}$, followed by a removal of part of the whey $(30 \%)$ and further heating of the curd to $40^{\circ} \mathrm{C}$ with the addition of hot water $\left(80^{\circ} \mathrm{C}\right)$, to obtain the correct consistency for Prato cheese. After heating, the whey was removed and the curd was placed in rectangular plastic molds $(0.5 \mathrm{~kg})$ and pressed atroom temperature in a vertical press with stainless steel weights. The cheeses were turned after 30 minutes $\left(1^{\text {st }}\right.$ pressing stage $)$ and after $1 \mathrm{~h}$ and $30 \mathrm{~min}\left(2^{\text {nd }}\right.$ pressing stage), with weights gradually increased 20 times the weight of the curd. The cheeses remained in the press for $12 \mathrm{~h}$ after the second pressing stage. After pressing was completed, cheeses were placed in a $20 \% \mathrm{NaCl}$ solution for a period of 10 hours at $5^{\circ} \mathrm{C}$. The cheeses were dried at $5^{\circ} \mathrm{C}$ for $24 \mathrm{~h}$ and finally sealed under vacuum in plastic bags and stored at $12^{\circ} \mathrm{C}$ for 65 days.

\section{Physicochemical composition}

After 5 days of manufacture, the cheeses were evaluated for $\mathrm{pH}$ by the potentiometric method, titratable acidity (AOAC, 2003), fat content by Gerber method (BRITISH STANDARDS INSTITUTION, 1989), moisture content by gravimetric method at $105^{\circ} \mathrm{C} / 16 \mathrm{~h}$ (AOAC, 2003), salt content by Volhard method (RICHARDSON, $1985)$ and ash content by incineration at $550^{\circ} \mathrm{C} / 12$ h (AOAC, 2003). Total nitrogen (TN) (IDF, 1962), soluble nitrogen in $12 \%$ trichloroacetic acid (NSTCA12\%) (AOAC, 2003) and soluble nitrogen at $\mathrm{pH} 4.6$ (NS-pH4.6) (BARBANO; LYNCH; FLEMING, 1991) were determined by the Kjeldahl method. The nitrogen values were multiplied by the factor 6.38 to obtain the equivalent amount of protein. All determinations were carried out in triplicate.

\section{Evaluation of proteolysis}

The cheeses were monitored for proteolysis after $5,25,45$ and 65 days of refrigerated storage $\left(12^{\circ} \mathrm{C}\right)$. Proteolysis was evaluated by the extent (EPI) and depth (DPI) of proteolysis indexes, according to the following equations: $\mathrm{EPI}=(\mathrm{NS}-\mathrm{pH} 4.6 / \mathrm{NT}) \times 100$ and DPI $=(\mathrm{NS}-\mathrm{TCA} 12 \% / \mathrm{NT}) \times 100$.

\section{Sensory evaluation}

The sensory evaluation of the cheeses was performed after 60 days of storage at $12^{\circ} \mathrm{C}$. Cheeses were evaluated by 50 untrained panelists in one session made in isolated sensory evaluation booths under white light. The samples at $12^{\circ} \mathrm{C}$ were served $(15 \mathrm{~g})$ in disposable white plates coded with three-digit numbers. Consumers were provided with water and unsalted crackers for palate cleansing. The attributes appearance, flavor, texture and overall impression were evaluated using a 9-point hedonic scale, where $1=$ dislike extremely and $9=$ like extremely. The purchase intention was measured on a five point scale where $1=$ definitely would not buy and 5 = definitely would buy (MEILGAARD; CIVILLE; CARR, 2006). The acceptance test results were evaluated by Analysis of Variance (ANOVA) and Tukey's test at 5\% significance level. The results of the purchasing intention were changed as percentage and evaluated using a frequency histogram.

\section{Experimental design and statistical analysis}

The statistical design adopted for this experiment was a split-plot block design, treatments being the plots and the cold storage the sub-plot. The effect of treatment, ripening period and the interaction of these factors on proteolysis were assessed by Analysis of Variance and Tukey's test at 5\% significance level. 


\section{Results and Discussion}

\section{Chemical composition of the cheeses}

Table 1 presents the chemical composition of the cheeses manufactured with or without adjunct cultures. Comparing the results found in this study (Table 1) to the regulation, the moisture and fat content on dry basis are in accordance with Brazilian law for all the samples. The addition of adjunct cultures of Lactobacillus plantarum and Lactobacillus helveticus did not significantly ( $\mathrm{p}>$ 0.05 ) affect the chemical composition of the cheeses.

Table 1. Average composition $(n=3)$ of the 5 day-old

cheeses produced with and without adjunct culture.

\begin{tabular}{lccc}
\hline Component & QC & Q14 & Q54 \\
\hline Moisture (\%) & $41.80^{\mathrm{a}}$ & $42.48^{\mathrm{a}}$ & $40.73^{\mathrm{a}}$ \\
Fat (\%) & $29.75^{\mathrm{a}}$ & $27.75^{\mathrm{a}}$ & $28.50^{\mathrm{a}}$ \\
FDM (\%) & $51.11^{\mathrm{a}}$ & $48.24^{\mathrm{a}}$ & $47.70^{\mathrm{a}}$ \\
Protein (\%) & $23.00^{\mathrm{a}}$ & $22.76^{\mathrm{a}}$ & $20.19^{\mathrm{a}}$ \\
Salt (\%) & $2.81^{\mathrm{a}}$ & $2.60^{\mathrm{a}}$ & $2.01^{\mathrm{a}}$ \\
Ash (\%) & $3.82^{\mathrm{a}}$ & $3.17^{\mathrm{a}}$ & $3.55^{\mathrm{a}}$ \\
Tritable acidity (\% lactic acid) & $0.76^{\mathrm{a}}$ & $0.95^{\mathrm{a}}$ & $1.23^{\mathrm{a}}$ \\
pH & $5.62^{\mathrm{a}}$ & $5.33^{\mathrm{a}}$ & $5.13^{\mathrm{a}}$ \\
\hline
\end{tabular}

*Means with the same letter, in the same line, do not differ $(\mathrm{p}>0.05) . \mathrm{FDM}=$ fat in dry matter. QC $=$ control cheese. Q14 $=$ cheese containing Lactobacillus plantarum. Q54 = cheese containing Lactobacillus helveticus.

Source: Elaboration of the authors.

Barros (2005) studied light Prato cheese added by Lactobacillus helveticus and by Lactobacillus casei, and observed that the adjunct culture did not influence the composition of the cheese. Awad, Ahmed and El Soda (2010) obtained similar results for Domiati cheese using mixtures of adjunct cultures containing Lactobacillus delbrueckii subsp. lactis, Lactobacillus paracasei subsp. paracasei, Lactobacillus plantarum, Lactobacillus rhamnosus, Lactobacillus casei and three strains of Enterococcus faecium.

\section{Evaluation of proteolysis}

The index $\mathrm{pH}$ 4.6-SN:TN increased significantly $(\mathrm{p}<0.05)$ (Table 2) for all the cheeses during the 65 days of ripening (Figure 1). The index $\mathrm{pH}$ 4.6-SN:TN evaluates the high molecular weight peptides formed in primary proteolysis due to the degradation of caseins mainly by the action of residual coagulant. The evolution of this index is an important factor for the final composition and the sensory characteristics of the cheese (CHOISY et al., 1987; FOX et al., 2000).

For all the treatments, there was a significant increase of the index 12\%TCA-SN:TN during ripening period (Table 2). The index 12\% TCA$\mathrm{SN}: \mathrm{TN} \%$ evaluates the small peptides and amino acids accumulated during ripening, mainly due to proteolytic action of bacterial proteases and peptidases on the nitrogen compounds released in the degradation of caseins. Small peptides and free amino acids contribute to the sensory characteristics of cheeses (FOX et al., 2000; MORENO et al., 2002). 
Figure 1. Extent of proteolysis index (EPI) of Prato cheese during the 65 days of ripening period.

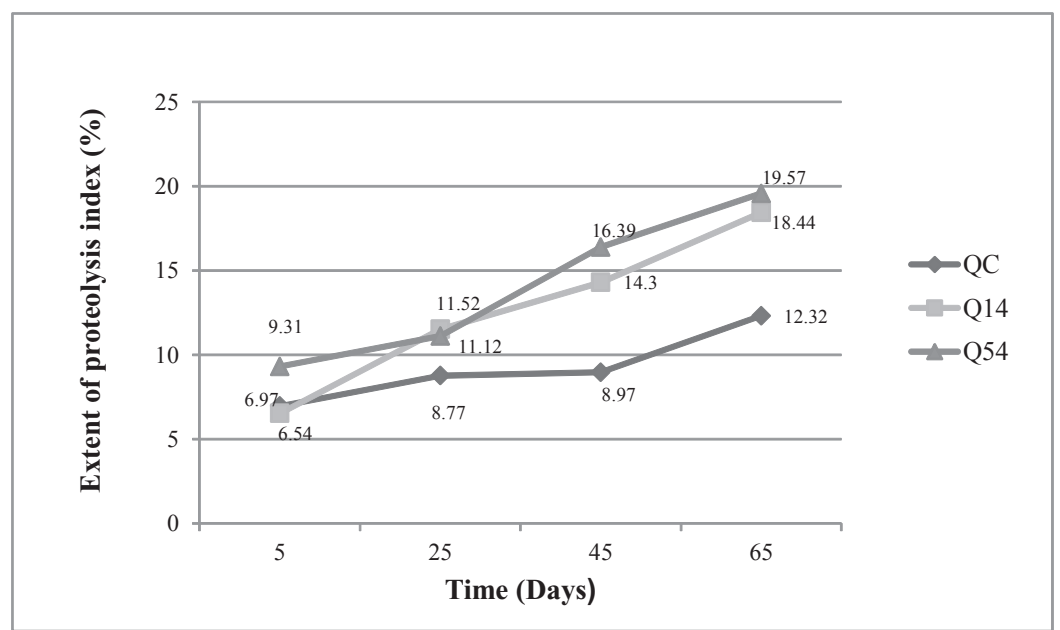

Source: Elaboration of the authors.

Table 2. Effect of treatment, ripening period, and their interactions on $\mathrm{pH}$ 4.6-soluble $\mathrm{N}$ (SN):totalN (TN), and $12 \%$ TCA-SN:TN of cheese with or without adjunct cultures $(n=3)$.

\begin{tabular}{|c|c|c|}
\hline Item & & \\
\hline & pH 4.6-SN:TN & 12\%TCA-SN:TN \\
\hline Treatment $^{(1)}$ & 0.2202 & 0.0290 \\
\hline Ripening period $^{(2)}$ & 0.0000 & 0.0000 \\
\hline Treatment $\times$ ripening period & 0.9599 & 0.3960 \\
\hline
\end{tabular}

${ }^{(1)}$ Treatament: chesse with and without adjunct culture; ${ }^{(2)} 65$ days.

$\mathrm{NS}=\mathrm{P}>0.05$

Source: Elaboration of the authors.

The degree of secondary proteolysis in terms of the $12 \%$ TCA-SN was higher in cheeses produced using L. helveticus than in cheeses produced using L. plantarum throughout the ripening period (Figure
2). These results showed that the higher proteolytic activity of $L$. helveticus could contribute to the $12 \%$ TCA-SN formation and consequently increased proteolysis for cheeses. 
Figure 2. Depth of proteolysis index (DPI) of Prato cheese during the 65 days of ripening period.

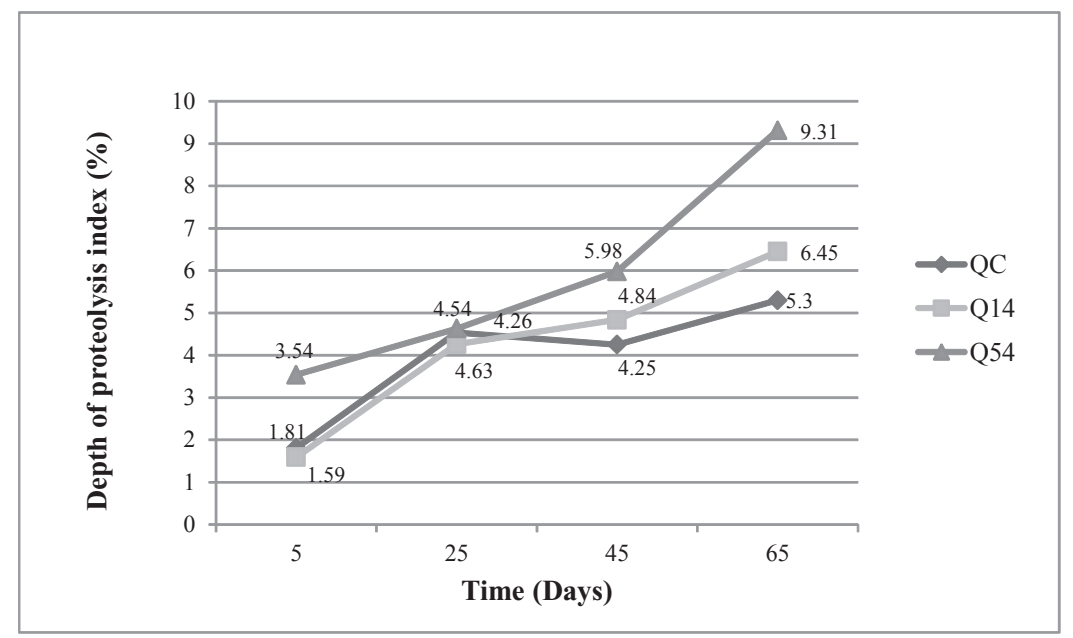

Source: Elaboration of the authors.

Kiernan et al. (2000) found that Cheddar cheeses containing $L$. helveticus as adjunct culture showed an increase in proteolysis and an improvement in flavor when compared to the control cheese. Barros (2005) studied Prato cheese containing L. casei or L. helveticus and observed an increase in the index $12 \%$ TCA-SN:TN of proteolysis for the cheese containing L.helveticus at 65 days of ripening.

\section{Sensory analysis}

The average scores obtained for the sensory attributes of the cheeses are shown in Table 3 . In general, the cheeses were well accepted by consumers, with scores between 6 and 7 (slightly to moderately liked) for all the sensory attributes studied.

Table 3. Average scores for sensory attributes of the cheeses with and without adjunct culture.

\begin{tabular}{lccc}
\hline Atribute & QC & $\mathbf{Q 1 4}$ & Q54 \\
\hline Appearance & $7,82^{\mathrm{a}}$ & $7,38^{\mathrm{a}}$ & $7,66^{\mathrm{a}}$ \\
Aroma & $7,44^{\mathrm{a}}$ & $7,08^{\mathrm{b}}$ & $7,62^{\mathrm{a}}$ \\
Flavor & $6,74^{\mathrm{b}}$ & $6,26^{\mathrm{b}}$ & $7,42^{\mathrm{a}}$ \\
Texture & $7,40^{\mathrm{b}}$ & $6,86^{\mathrm{c}}$ & $7,78^{\mathrm{a}}$ \\
Overall Impression & $7,50^{\mathrm{a}}$ & $7,12^{\mathrm{a}}$ & $7,24^{\mathrm{a}}$ \\
\hline
\end{tabular}

*Means with the same letter, in the same line, do not differ $(\mathrm{p}>0,05)$. QC = control cheese. Q14= cheese containing Lactobacillus plantarum. Q54 = cheese containing Lactobacillus helveticus.

Source: Elaboration of the authors.

The cheese containing L. helveticus (Q54) showed higher acceptability for flavor and texture attributes than the other samples. However, there was no difference between the samples for the attributes appearance and overall impression.

Proteolysis plays a critical role in determining the typical sensory characteristics and represents a significant indicator of quality (flavor and texture) (KARIMI; MORTAZAVIAN; KARAMI, 2012). Bacterial cell wall associated proteinases and intracellular peptidases released after cell lysis in the curd are considered to play an important role in casein hydrolysis during cheese preparation (WILKINSON et al., 1994). The differences of 
flavor and texture attributes can be related to the greater proteolysis of the cheese Q54 when compared to control cheese and Q14 (see Figure 2).

Improvement in cheese flavor can be linked to the high levels of free amino groups in cheese made with the adjunct culture that possess considerable levels of aminopeptidolytic activity (PIROUZIAN et al., 2012). According to Slattery et al. (2010), the L. helveticus is often used as adjunct culture in order to enhance the flavor of cheese. The results found in our study are in agreement with previously reported results. Barros et al. (2006) found that Prato cheese containing $L$. helveticus as adjunct culture showed a texture improvement probably due to the action of the proteolytic system of this microorganism on the casein matrix. In another study, Fenelon, Beresford and Guinee (2002) used various types of cultures containing combinations of Lactococcus and adjunct cultures (including various strains of $L$. helveticus) and found that the adjunct culture improved flavor and increased the acceptability of low-fat Cheddar cheese when compared to control cheese containing only Lactococcus.

Figure 3 shows the frequency histogram for purchase intention. A better flavor perception for the cheese Q54 reflected positively on the buying intention of consumers. About $80 \%$ of the panelists certainly or probably buy the Prato cheese containing L. helveticus as adjunct culture (Q54), indicating a better acceptability of this cheese when compared to control cheese (QC) and cheese containing $L$. plantarum (Q14).

Figure 3. Frequency histogram analysis for buying intention for Prato cheese with or without adjunct culture.

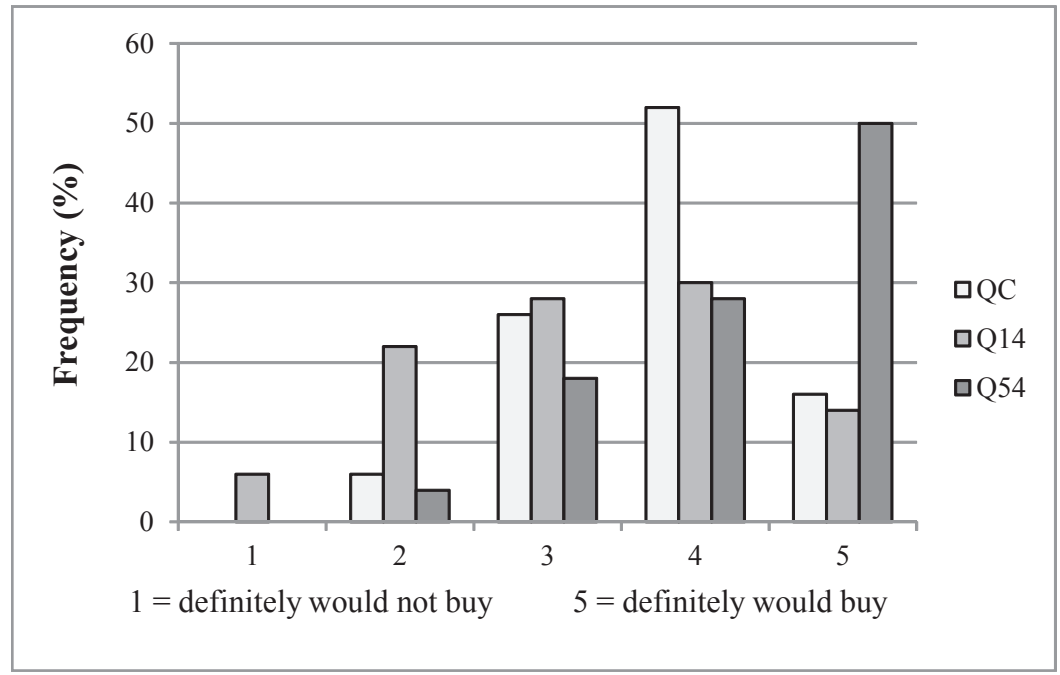

Source: Elaboration of the authors.

\section{Conclusion}

The most pronounced impact of the addition of adjunct culture on Prato cheese was observed on the proteolysis index and on the organoleptic properties of the ripened cheese. The addition of $L$. helveticus showed technological potential to accelerate ripening and, consequently, to improve the sensory characteristics of the Prato cheese.

\section{Acknowledgments}

The authors are thankful for Fundação Nacional de Desenvolvimento do Ensino Superior Particular (FUNADESP, Brazil) for financial support. 


\section{Notes}

This study was approved by the "Comitê de ética e biossegurança da Universidade Norte do Paraná (CAAE - 0087.0.078.000-10)" and was carried out according with biosecurity and bioethics rules.

\section{References}

ASSOCIATION OF OFFICIAL ANALYTICAL CHEMISTS - AOAC. Official methods of analysis. $17^{\text {th }}$ ed. Washington DC: Association of Official Analytical Chemists, 2003.

AWAD, S.; AHMED, N.; ELSODA, M. Influence of microfiltration and adjunct culture on quality of Domiati cheese. Journal of Dairy Science, Champaign, v. 93, n 5, 1807-1814, may 2010.

BARBANO, D. M.; LYNCH, J. M.; FLEMING, J. R. Direct and indirect determination of true protein content of milk by kjeldahl analysis: collaborative study. Journal of Association of Official Analytical Chemists, Gaithersburg, v. 74, n. 2, p. 281-288, 1991.

BARROS, C. M. V. Uso de culturas adjuntas e ultrafiltração para melhoria de sabor e textura de queijo prato com reduzido teor de gordura. 2005. Tese (Doutorado em Tecnologia de Alimentos) - Faculdade de Engenharia de Alimentos. Universidade Estadual de Campinas, Campinas.

BARROS, C. M. V.; CUNHA, C. R.; GALLINA, D. A.; VIOTTO, L. A.; VIOTTO, W. H. Efeito do uso de cultura adjunta (Lactobacillus helveticus) na proteólise, propriedades viscoelásticas e aceitação sensorial de queijo Prato light. Ciência e Tecnologia de Alimentos, Campinas, v. 26, n. 1, p. 11-18, jan./mar. 2006.

BRASIL. Ministério da Agricultura, Pecuária e Abastecimento. Portaria $\mathrm{N}^{\circ} 358$ de 04 de setembro de 1997. Regulamento técnico para fixação de identidade e qualidade do queijo Prato. Available at: $<\mathrm{http}$ ://www. agais.com/normas/leite/queijo_prato.htm>. Accessed at: 31 jan. 2012.

BRITISH STANDARDS INSTITUTION. Determination of fat content of milk and milk products (Gerber methods). Methods. London: British Standards Institution, 1989. 12 p.

CHOISY, C.; DESMAZEAUD, M.; GRIPON, J. C.; LAMBERET, G.; LENOIR, J.; TOURNEUR, C. Les phénomènes microbiologiques et enzymatiques et la biochimie de l'affinage. In: ECK, A. (Ed.). Le fromage. Paris: Techinique et documentation, 1987. p. 62-100.
COSTA JÚNIOR, L. C. G.; PINHEIRO, A. J. R. Influência da relação caseína/gordura nas características físico-químicas do queijo Prato. Revista do Instituto de Laticínios Cândido Tostes, Juiz de Fora, v. 53, n. 305, p. 29-49, 1998.

DRAKE, M. A.; BOYLSTON, T. D.; SWANSON, B. G. Chemical and sensory effects of Lactobacillus adjunct in cheddar cheese. Food Research International, Essex, v. 29, n. 3-4, p. 381-387, 1996.

DRAKE, M. A.; SWANSON, B. G. Reduced and low-fat cheese technology: a review. Trends in Food Science and Technology, Colney, v. 6, n. 11, p. 366-369, 1995.

FENELON, M. A.; BERESFORD, T. P.; GUINEE, T. P. Comparison of different bacterial culture systems for the production of reduced-fat Cheddar cheese. International Journal of Dairy Technology, Singapore, v. 55, n. 4, p. 194-203, 2002.

FOX, P. F. Developments in the biochemistry of cheese ripening. In: INTERNATIONAL DAIRY CONGRESS, 25., 1998, Proceedings... Denmark: Aarhus, 1998. p. 123-128.

FOX, P. F.; GUINEE, T. P.; COGAN, T. M.; McSWEENEY, P. L. H. Fundamentals of cheese science. Gaithersburg: Aspen Publishers, Inc., 2000. 587 p.

FOX, P. F.; SINGH, T. K.; MCSWEENEY, P. L. H. Biogenesis of flavor compounds in cheese. In: MALIN, E. L.; TUNICK, M. H. (Ed.). Chemistry of structure function relationships in cheese. New York: Plenum Press, 1995. p. 59-98.

INTERNATIONAL DAIRY FEDERATION - IDF. Determination of the total nitrogen content of milk by the kjeldahl method. IDF-FIL, Brussels, n. 20, p. 1-3, 1962.

KARIMI, R.; MORTAZAVIAN, A. M.; KARAMI, M. Incorporation of Lactobacillus casei in Iranian ultrafiltered Feta cheese made by partial replacement of $\mathrm{NaCl}$ with $\mathrm{KCl}$. Journal of Dairy Science, Champaign, v. 95, n. 8, p. 4209-4222, aug. 2012.

KIERNAN, R. C.; BERESFORD, T. P.; O'CUINN, G.; JORDAN, K. N. Autolysis of lactobacilli during Cheddar cheese ripening. Irish Journal of Agricultural and Food Research, Carlow, v. 39, n. 1, p. 95-106, 2000.

MEILGAARD, M.; CIVILLE, G. V.; CARR, B. T. Sensory evaluation techniques. 4. ed. Boca Raton: CRC Press, 2006, 448 p.

MISTRY, V. V. Low fat cheese technology. International Dairy Journal, Barking, v. 11, n. 4-7, p. 413-422, july 2001. 
MORENO, I.; VAN DENDER, A. G. F.; COSTA, G. A. N.; VIALTA, A.; LERAYER, A. L. S.; SILVA, A. T.; DESTRO, M. T. Propriedades físicas e composição química e bioquímica durante a maturação de queijo Prato de diferentes origens. Revista do Instituto de Laticínios Cândido Tostes, Juiz de Fora, v. 57, n. 327, p. 270-273, 2002.

PIROUZIAN, H. R.; HESARI, J.; FARAJNIA, S.; MOGHADDAM, M.; GHIASSIFAR, S. H. Effects of Enterococcus faecalis and Enterococcus faecium, isolated from traditional lighvan cheese, on physicochemical and sensory characteristics of iranian uf white cheese. Journal of Agricultural Science and Technology, Tehran, v. 14, n. 5, p. 1023-1034, sept. 2012.

RICHARDSON, G. H. Standard methods for examination of dairy products. Washington: American Public Health Association, 1985. 412 p.

SILVA, A. T.; MORENO, I.; VAN DENDER, A. G. F.; VIALTA, A. Efeito da redução do teor de gordura na população microbiana e na formação de flavor do queijo. Revista Indústria de Laticínios, São Paulo, n. 50, p. 5861, 2004.
SILVA, A. T.; VAN DENDER, A. G. F.; BALDINI, V. L. S. Perfil eletroforético do queijo tipo Prato obtido com incorporação de enzimas proteolíticas. Revista do Instituto de Laticínios Cândido Tostes, Juiz de Fora, v. 54, n. 311, p. 150-156, 1999.

SIUFE, G. A.; ZORRILlA, S. E.; RUBIOLO, A. C. The influence of ripening temperature and sampling site on the proteolysis in Reggianito Argentino cheese. LWTFood Science and Technology, Zurich, v. 43, n. 2, p. 247253, mar. 2010.

SLATTERY, L.; O'CALLAGHAN, J.; FITZGERALD, G. F.; BERESFORD, T.; ROSS, R. P. Invited review: Lactobacillus helveticus - a thermophilic dairy starter related to gut bacteria. Journal of Dairy Science, Champaign, v. 93, n. 10, p. 4435-4454, oct. 2010.

SOUZA, M. J.; ARDÖ, Y.; MCSWEENEY, P. L. H. Advances in the study of proteolysis during cheese ripening. International Dairy Journal, Barking, v. 11, n. 4-7, p. 327-345, july 2001.

WILKINSON, M. G.; GUINEE, T. P.; O’CALLAGHAN, D. M.; FOX, P. F. Autolysis and proteolysis in different strains of starter bacteria during Cheddar cheese ripening. Journal of Dairy Research, London, v. 61, n. 2, p. 249262, may 1994. 
